\title{
Description of Immature Stages of Lasioseius lindquisti Nasr and Abou-Awad (Mesostigmata: Ascidae) with Notes on its Ontogeny
}

\author{
A. K. Nasr ${ }^{*}$; A. M. Metwally ${ }^{* *}$; Magda, M. Abou-Elela* and Kh. M. A.Saleh ${ }^{*}$ \\ ${ }^{*}$ Pests and Plant Protection Dept. , National Research Center ,Dokki, Giza, Egypt \\ **Agricultural Zoology Dept., Faculty of Agric., AL-Azhar University, Cairo, Egypt
}

\begin{abstract}
The ascid mite Lasioseius lindquisti Nasr \& Abou-Awad, was collected from waterhyacinth plant (Eichhorina crassipes Mart). The immature stages are decribed and illustrated with notes on its ontogeny.
\end{abstract}

Key Words: Lasioseius lindquisti, Description, Immature stages, Ontogeny.

\section{INTRODUCTION}

During a survey on mites associated with the waterhyacinth, Eichhorina crassipes Mart and the aquatic weeds in Egypt (Under publication) Lasioseius lindiquisti was collected and reared. Lindquist and Evans (1965) reviewed and discussed the previous taxonomic concepts to find out a modified system of nomenclature for setae on the dorsum of the idiosoma and the venter of the opisthoma, using Lasioseius alli Chant, with its postembryonic development. Genus Lasioseius is probably the most morphologically disparate genus of Ascidae. Approximately 100 species have been described (Halliday et al. 1998); but little articles dealing with description of their immature stages and their ontogeny were reported.

In Egypt, some studies have been done dealing with description of the immature stages of this genus, but their ontogeny have not been studied before (EL-Bishlawy, 1978; Afifi, 1982; Nasr et al. 1990; Nawar et al. 1990 and Nawar \& El- Sherif, 1992).

This study aimed to describe and illustrate the postembrynic stages of $L$. lindquisti and its ontogeny.

\section{MATERIALS AND METHODS}

Five specimens of each larval, protonymphal, and dutonymphal stages, were cleaned in Nesbitt's solution before mounting in Hoyer's medium. Eyepiece camera was used for drawing the specimens. The systems of notation of morphological structure and chaetotaxy of idosoma, follow those of Lindquist \& Evans (1965), and Evans (1963) for the legs. All measurements are in millimicrons $(\mu \mathrm{m})$. The specimens are deposited in the collection of the National Research Center,
Dokki, Egypt.

\section{RESULTS AND DISCUSSION}

Description of Egg and Immature stages:

Egg:

Oval, white, translucent, 132 long and 112 wide.

Larva: Dorsum: (Fig. 1a)

Idiosoma 197-240 long (5 specimens) and 127-160 wide at level of legs III; with lightly sclerotized and smooth podontal shield. Body bears 15 pairs of simple setae: 9 pairs $\left(\mathrm{j}_{1}, \mathrm{j}_{3}-\mathrm{j}_{6}, \mathrm{z}_{2}, \mathrm{z}_{4}\right.$, $\mathrm{Z}_{5}, \mathrm{~s}_{4}$ ) on podontal region, while 6 pairs of satae on membrane of opisthonatal region $\left(Z_{3}-Z_{5}, S_{3}, S_{4}\right.$ and $S_{5}$ ) the last two pairs of setae placed so far ventralaterally, setae $Z_{4}$ and $Z_{5}$ flagellated and the longest. Length of some dorsal setae:

$$
\begin{aligned}
& \mathrm{j}_{1}=18, \\
& \mathrm{z}_{4}=25
\end{aligned} \quad \begin{aligned}
& \mathrm{j}_{6}=26 \\
& \mathrm{~s}_{4}=38
\end{aligned}
$$

\section{Venter: (Fig. 1b)}

Tritosternum with a slender base and well developed pair of setoses laciniae; sternal shield littly distinct, with 3 pairs of sternal setae; opsisthogaster with 4 pairs of setae $\left(\mathrm{Jv}_{1}, \mathrm{Jv}_{2}, \mathrm{Jv}_{5}\right.$, and $\mathrm{Zv}_{2}$ ) in addition to the 3 anal setae; anal shield weakly sclerotized; post anal and paranal setae wep-like and longer than other ventral setae. Length of some ventral setae;

$$
\begin{aligned}
& \mathrm{st}_{1}=12, \quad \mathrm{jv}_{1}=6 \text {, } \\
& \text { postanals }=14 \text { and para-anals }=25 \text {. }
\end{aligned}
$$

Hypostome with anterior rostal and external posteriore rostral simple setae; corniculi horns and parallel; deutosternum with 7 transverse denticles rows;tectum. (Fig. 1d) weakly defined with anterior denticulate margin; chelicerae (Fig. 1e) movable digit length $=18$ with 3 teeth, while the fixed multidenticulated, with short and setiform pilus dentilis. 

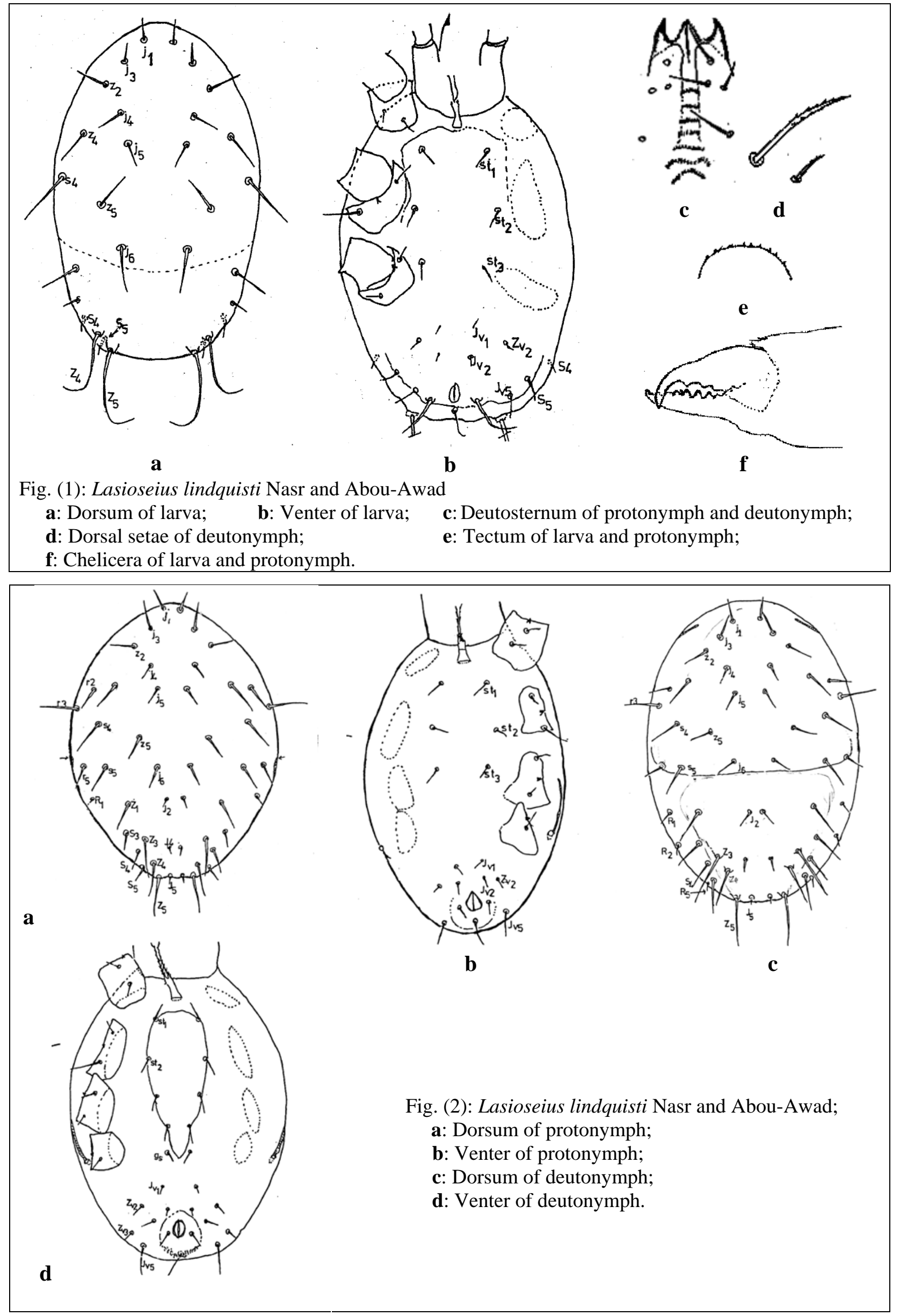
Chaetotactic formulae of genua and tibiae of legs as follows:

\begin{tabular}{ccccccc}
\hline & \multicolumn{1}{c}{ I } & \multicolumn{2}{c}{ II } & III \\
\hline Genu & $1 \frac{2}{1}$ & $\frac{2}{1} 1$ & $1 \frac{2}{0}$ & $\frac{2}{0} 1$ & $1 \frac{2}{0}$ & $\frac{2}{0} 1$ \\
\hline Tibia & $1 \frac{2}{1}$ & $\frac{2}{1} 1$ & $1 \frac{1}{1}$ & $\frac{2}{1} 1$ & $1 \frac{2}{1}$ & $\frac{1}{1} 1$ \\
\hline
\end{tabular}

Protonymph: Dorsum (Fig. 2a).

Idiosoma 218-250 long and 154-188 wide at level of legs III. Body elliptical, white to yellow when alive, with 4 pairs of legs. Dorsum weakly sclerotized, bearing 13 pairs of setae on anterior region which are $\mathrm{j}_{1}, \mathrm{j}_{3}-\mathrm{j}_{6}, \mathrm{z}_{2}, \mathrm{z}_{4}, \mathrm{z}_{5}, \mathrm{~s}_{4}, \mathrm{~s}_{5}, \mathrm{r}_{2}, \mathrm{r}_{3}$, and $\mathrm{r}_{5}$, while posterior dorsal region bearing 11 pairs of setae which are: $J_{2}, J_{4}, J_{5}, Z_{1}, Z_{3}-Z_{5}, S_{3}-S_{5}$ and $R_{1}$, all dorsal setae pilose distally (Fig. 1d).

\section{Venter: (Fig. 2b)}

Tritosternum normal as in larva; sternal shield weakly sclerotized with 3 pairs of sternal setae and 2 pairs of lyrifissures; opisthogaster with 4 pairs of setae as in larva; anal shield weakly defined, postonal setae twice as long as para-anals; peritreme short, not passthrough coxae III.

Hypostome (Fig. 1c) with anterior rostal and external posterior rostral setae, internal posterior rostral and capitular setae present. Corniculi, deutosternum, tecum and chelicerae nearly as in larva with more sclerotization and size.

Chaetotactic formulae of genua and tibiae of legs as follows:

\begin{tabular}{ccccccc}
\hline & I & II & III & IV \\
\hline Genu & $1 \frac{2}{1} \frac{2}{1} 1$ & $1 \frac{2}{0} \frac{2}{0} 1$ & $1 \frac{2}{0}$ & $\frac{2}{0} 1$ & $1 \frac{2}{0}$ & $\frac{2}{0} 0$ \\
\hline Tibia & $1 \frac{2}{1} \frac{2}{1} 1$ & $1 \frac{1}{1} \frac{2}{1} 1$ & $1 \frac{2}{1} \frac{1}{1} 1$ & $1 \frac{1}{1} \frac{2}{1} 1$ \\
\hline
\end{tabular}

Deutonymph: Dorsum (Fig. 2c).

Idiosoma 238-275 long and 166-190 wide at level of legs III. Body oval, cream when alive, dorsum weakly sclerotized bearing 13 pairs of setae on anterior region which are; $j_{1}, j_{3}-j_{6}, z_{2}, z_{4}, z_{5}, s_{4}$, $\mathrm{s}_{5}, \mathrm{r}_{2}, \mathrm{r}_{3}$ and $\mathrm{r}_{5}$, posterior region having 13 pairs of setae which are: $\mathrm{J}_{2}, \mathrm{~J}_{4}, \mathrm{~J}_{5}, \mathrm{Z}_{1}, \mathrm{Z}_{3}-\mathrm{Z}_{5}, \mathrm{~S}_{3}-\mathrm{S}_{5}, \mathrm{R}_{1}, \mathrm{R}_{2}$ and $\mathrm{R}_{5}$, all dorsal setae finely pilose at the distal half of setae. Length of some dorsal setae: $\mathrm{j}_{1}=20$, $r_{3}=31, s_{5}=28, Z_{1}=31.5, Z_{3}=35, Z_{5}=39$.

\section{Venter: (Fig. 2d).}

Tritosternum normal. Sternogenital shield weakly sclerotized, with 4 pairs of setae and 3 pairs of pores; a pair of genital setae on integument of genital area; opisthogasteric region with 6 pairs of ventral setae $\left(\mathrm{Jv}_{1}-\mathrm{Jv}_{3}, \mathrm{Jv}_{5}, \mathrm{Zv}_{2}\right.$ and $\left.\mathrm{Zv}_{3}\right)$. Anal shield semi-circuler; postanal setae twice as long as paranals; peritreme long extending dorsally to level of setae $\mathrm{j}_{1}$. Length of some ventral setae, $\mathrm{st}_{1}=14$, postanals $=20$. Hypostome, corniculi, deutosternum (Fig.1c), tectum and chelicerae as in protonymph.

Chaetotactic formulae of genua and tibiae of legs as follows:

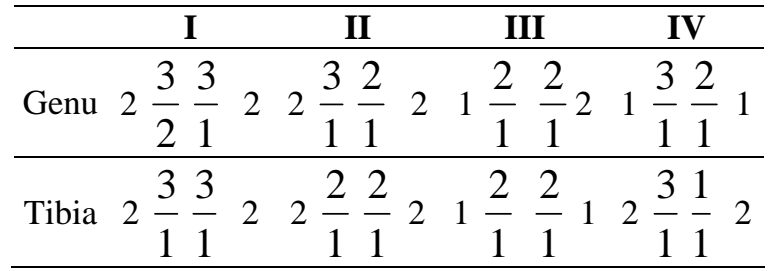

Ontogenetic development of setae on immatures of Lasioseius lindquisti Naser \& Abou-Awad

\begin{tabular}{|c|c|c|c|c|c|c|c|}
\hline \multicolumn{2}{|c|}{$\begin{array}{c}\text { Dorsocentral } \\
\text { Series }\end{array}$} & \multicolumn{2}{|c|}{$\begin{array}{c}\text { Mediolateral } \\
\text { Series }\end{array}$} & \multicolumn{2}{|c|}{$\begin{array}{c}\text { Lateral } \\
\text { Series } \\
\end{array}$} & \multicolumn{2}{|c|}{$\begin{array}{c}\text { Marginal } \\
\text { Series }\end{array}$} \\
\hline Setae & Stage & Setae & Stage & Setae & Stage & Setae & Stage \\
\hline \multicolumn{8}{|c|}{ Anterior region (Podonotum) } \\
\hline $\mathrm{j}_{1}$ & (La) & $\mathrm{z}_{2}$ & $(\mathrm{La})$ & $\mathrm{s}_{4}$ & $(\mathrm{La})$ & $\mathrm{r}_{2}$ & $(P n)$ \\
\hline $\mathrm{j}_{3}$ & (La) & & & & & & \\
\hline $\mathrm{j}_{4}$ & (La) & $\mathrm{z}_{4}$ & (La) & & & $\mathrm{r}_{3}$ & $(P n)$ \\
\hline $\mathrm{j}_{5}$ & (La) & & & $\mathrm{S}_{5}$ & $(P n)$ & & \\
\hline $\mathrm{j}_{6}$ & $(\mathrm{La})$ & $\mathrm{z}_{5}$ & $(\mathrm{La})$ & & & $\mathrm{r}_{5}$ & $(P n)$ \\
\hline \multicolumn{8}{|c|}{ Posterior region (Opisthonotum) } \\
\hline $\mathrm{J}_{2}$ & $(P n)$ & $\mathrm{Z} 1$ & $(\mathrm{Pn})$ & $\mathrm{S}_{3}$ & $(\mathrm{La})$ & $\mathrm{R}_{1}$ & $(P n)$ \\
\hline $\mathrm{J}_{4}$ & $(P n)$ & $\mathrm{Z3}$ & (La) & $\mathrm{S}_{4}$ & $(\mathrm{La})$ & $\mathrm{R}_{2}$ & (Dn) \\
\hline \multirow[t]{2}{*}{$\mathrm{J}_{5}$} & $(P n)$ & $\mathrm{Z} 4$ & (La) & $\mathrm{S}_{5}$ & $(\mathrm{La})$ & $\mathrm{R}_{5}$ & (Dn) \\
\hline & & $\mathrm{Z} 5$ & (La) & & & & \\
\hline
\end{tabular}

The letter in parentheses indicates the stage in which the seta appears during postembryonic development: $\mathrm{La}=$ larva, $\mathrm{Pn}=$ protonymph, $\mathrm{Dn}=$ dutonymph.

\section{Notes}

- The cheliceral digits (Fig.1e), the seven transverse rows of deutosternal denticles (Fig. 1c), and the tectum (Fig. 1d), with more sclerotization, are relatively constant ontogenetically in L. lindquisti.

- The number, arrangement, and ontogenetic development of setae on genual, and tibial segments of legs are similar in larvae and protonymphs of all ascids (Lindquist \& Evans 1965) and are like those described for Pergamasus by Evans (1963).

The trend of ontogeny in L. lindquisti is similar to many species as: $L$. berlesei (Oudemans), L. parberlesei Bhattacharya, L. youcifi AthiasHenriot, L .mcgregory Chant, L. phytoseioides Chant, and L. peritremes Nasr \& Abou-Awad. Those are having hypotrichous conditions, wheras the dorsal shield in the deutonymphs and the adults are bearing 22-23 pairs of setae. 


\section{REFERENCES}

Afifi, A. M. 1982. Lasioseius aegypticus a new species from Egypt, with notes on its biology (Acari: Gamasida: Ascidae). Proc. Egypt's National Conf. Ent., Dec. Vol. I: 453-461.

El-Bishalawy, S. M. 1978. Ecological and biological studies on mites associated with weeds, with special reference to lawn grasses Ph.D. Thesis, Faculty of Agric.,Cairo Univ. Egypt, 148pp.

Evans, G. O. 1963. Observation on the chaetotaxy of the legs in the free-living Gamasina (Acari: Mesostigmata). Bull. Brit. Mus. (Nat.Hist) Zool., 10:277-303.

Halliday, R. B.; Walter, D. E. and Lindquist, E. 1998. Revision of the Australian Ascidae (Acari: Mesostigmata) Invertebrate Taxonomy, 12:1-54.

Lindquist, E. E. and Evans, G. O. 1965. Taxonomic concept in the Ascidae,with amodified setae nomenclature for the idiosoma of the Gamasina (Acarina :Mesostigmata) Memoirs of the Entom . Soc. of Canada, 47: 1-64.

Nasr, A. K. and Abou-Awad, B. A. 1987. Description of some ascid mites from Egypt (Acari: Ascidae) Acarologia, 28: 27-35.

Nasr, A. K.; Nawar, M. S and Mowafi, M. H. 1990. Biological studies and feeding habits of Lasioseius athiasae Nawar and Nasr (Acari: Mesostigmata: Ascidae) in Egypt. Bull. Zool. sci. Egypt, 39: 75-88.

Nawar, M. S.; Rakha, M. A. and Ali, F. S. 1990. Laboratory studies on the predaceous mite, Lasioseius bispinosus Evans, (Acari: Mesostigmata: Ascidae) on various kinds of food substances. Bull. Soc. Ent. Egypte, 69: 247-255.

Nawar, M. S and El-Sherif, A. A. 1992. Biological studies and description of developmental stages of Lasioseius zaheri Nasr (Acari:Ascidae). Ann. Agric. Sci. Moshtohor, 30(1): 581-589. 